\title{
First serodetection and molecular phylogenetic documentation of Coxiella burnetii isolates from female camels in Wasit governorate, Iraq
}

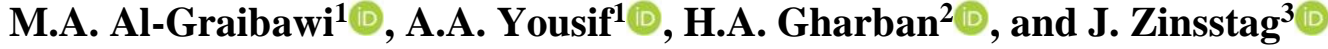 \\ ${ }^{1}$ Department of Internal and Preventive Veterinary Medicine, College of Veterinary Medicine, University of Baghdad, \\ ${ }^{2}$ Department of Internal and Preventive Veterinary Medicine, College of Veterinary Medicine, Wasit University, Wasit, Iraq, \\ ${ }^{3}$ Departments of Epidemiology and Public Health, Swiss Tropical and Public Health Institute, Basel, Switzerland
}

\begin{tabular}{l} 
Article information \\
\hline Article history: \\
Received May 18, 2020 \\
Accepted October 10, 2020 \\
Available online December 1, 2021 \\
\hline Keywords: \\
Q fever \\
Camelus dromedarius \\
PCR \\
Sequence \\
ELISA
\end{tabular}

Correspondence:

A.A. Yousif

afaf.a@covm.uobaghdad.edu.iq

\begin{abstract}
This study aims to detect Coxiella burnetii in one-humped female camels (Camelus dromedarius) using ELISA and confirmation of infection by PCR with the phylogenetic analysis of local isolates. The 91 adult female camels were selected for clinical examination and blood sampling from different areas in Badra and Al-Numaniyah districts in Wasit governorate, Iraq, from February to April 2019. The prevalence of Coxiella (C.) burnetii was $19.8 \%$ and $4.4 \%$ by ELISA and PCR, respectively. Targeting 16S rRNA genes from three positive samples were documented in the Genbank-NCBI under accession numbers of MN900579.1, MN900580.1, and MN900581.1. Clinical evaluation revealed insignificant variation in temperature, pulse, respiratory rates, and lymph node enlargement among the positive and negative animals. The findings also showed that camels of the Badra regions have positive signs. burnetii compared to other regions, and the infection was increased significantly in April and March. In conclusion, our findings confirmed the prevalence of C. burneth among Iraqi female camels, suggesting that these animals might be a source of the pathogen for humans and other animal species. Therefore, further studies are necessary to provide more detailed data about the prevalence of $C$. burnetiito to improve effective control measures.
\end{abstract}

DOI: 10.33899/ijvs.2021.130888.1890, (CAuthors, 2021, College of Veterinary Medicine, University of Mosul.

This is an open access article under the CC BY 4.0 license (http://creativecommons.org/licenses/by/4.0/).

\section{Introduction}

The Coxiella $(C$.) burnetii is an obligate intracellular, Gram-negative, non-motile bacterium belonging to the Coxiellaceae family of Legionellales order, which causes a highly contagious neglected zoonotic disease known as Q (Query) fever (1). Many studies reported that this pathogen is considered a potential agent for bioterrorism due to its highly high infectivity (one bacterium may produce disease) in humans and a wide range of domestic and wild animals and its survival under harsh environmental conditions (2). $C$. burnetii is an occupational pathogen of farmers, slaughterhouse workers, and veterinarians and can be transmitted by inhaling aerosolized contaminated dust, direct contact with infected tissues and fluids, as well as by arthropod bites (3). Multiple hosts can serve as the main reservoir for infection, particularly the infected females that shed vast numbers of highly stable bacteria into their birth products (amniotic fluids and placenta) and smaller amounts in milk, feces, and urine which may continue over several months (4-6). Worldwide, numerous studies investigate the prevalence of Coxiella in camels such as the United Arab Emirates (7), Egypt (8), Algeria (9), Saudi Arabia (10), and Iran (11). These studies showed that the prevalence of $C$. burnetii varies widely by geographical location, type of management, and flock numbers. ELISA is the most recommended and preferred diagnostic technique for $\mathrm{Q}$ fever and other diseases for screening assays and epidemiological studies because of its high specificity and sensitivity, relatively low cost, and easier to use $(11,12)$. For confirmation, the isolation of $C$. burnetii by inoculation of the yolk sac of 5-7 old chick embryos or in vitro tissue 
culture has been difficult, time-consuming, hazardous, and requires biosafety level 3 laboratories (1). Molecular assays are beneficial and safe methods with high specificity and sensitivity and decrease the time for detecting targeted $C$. burnetii DNA in suspected samples (4). Serological assays and direct detection by PCR must be used as combinatory methods to diagnose infection (5). In Iraq, the dromedary camel (Camelusdromedarius) is one of the most important domesticated animals in arid and semi-arid areas. It is a source of milk, meat, wool, and leather, mainly for Bedouin communities (13).

Nonetheless, there are no data or studies about the detection of $C$. burnetii in camels. Furthermore, the biological management and veterinary care for camels in Iraq lag behind those for other animals such as sheep, goats, and cattle; this may decrease productivity due to diseaserelated morbidity and mortality. Hence, the present study was designed to investigate the seroprevalence of $C$. burnetii in adult female camels using the ELISA to detect the bacterium by PCR for subsequence phylogenetic analysis.

\section{Materials and methods}

\section{Ethical approval}

Approval for the present study was obtained from the College of Veterinary Medicine, University of Baghdad, Baghdad, and the College of Veterinary Medicine, Wasit University, Wasit, Iraq.

\section{Samples}

Ninety-one adult female camels were selected randomly from different areas in Badra and Al-Numaniyah districts in Wasit governorate, Iraq, from February to April 2019. Each animal was examined clinically, and the data regarding vital signs (temperature, pulse, and respiratory rates), examination of scapular and supra-mammary lymph nodes, tick's infestation, and reproductive status (number of pregnancies, abortions, stillbirths, and milk production) were reported. Additionally, $10 \mathrm{ml}$ of jugular venous blood was drained from each camel under aseptic conditions and divided equally into without- and with-anticoagulant (EDTA) tubes to be used for serology and molecular assay, respectively. After centrifugation (3000 rpm / 10 minutes), the serum sample of each animal was kept in a labeled Eppendorf tube. Both sera and whole blood samples were stored frozen at $20^{\circ} \mathrm{C}$ until analysis.

\section{Serology}

Camel C. burnetii ELISA kit (SunLong, China) was used to detect the anti $-C$. burnetii $\operatorname{IgG}$ antibodies according to manufacturer's instructions and protocols. The serum samples were analyzed and read at $450 \mathrm{~nm}$ optical density (OD) using an automatic plate reader (BioTek, USA). The cut-off got 0.471 , and it was at the mean of the negative OD +0.15 .

\section{Molecular testing}

The genomic DNA of $C$. burnetii was extracted from whole blood samples according to the manufacturer's instruction of G-spin total DNA extraction mini kit (iNtRON, Biotechnology, South Korea). The purity and concentration of extracted DNA were measured using a Nanodrop spectrophotometer (Thermo-Scientific, UK). The PCR premix (Bioneer, South Korea) and the primer (4) [(F: 5'-AGTACGGCCGCAAGGTTAAA-3') and (R: 5'CTCCAATCCGGACTACGAGC-3')] of 16S rRNA gene at $20 \mu \mathrm{l}$ final volume were carried out to amplify $C$. burnetii DNA at $425 \mathrm{bp}$. The PCR reaction was performed by Thermal-Cycler (Bio-Rad, USA) utilizing the following optimized conditions: 1 cycle $\left(95^{\circ} \mathrm{C} / 5 \mathrm{~min}\right.$.) for initial denaturation, 30 cycles comprised $\left(95^{\circ} \mathrm{C} / 40\right.$ sec.) denaturation, $\left(56^{\circ} \mathrm{C} / 40 \mathrm{sec}.\right)$ annealing, and $\left(72^{\circ} \mathrm{C} / 1 \mathrm{~min}\right.$.) extension for each one, and followed by one cycle $\left(72^{\circ} \mathrm{C} / 7\right.$ minutes) for the final extension. Electrophoresis in $1.5 \%$ agarose gel was examined the PCR products using 100-1500 bp of DNA ladder (Qiagen, Germany). The agarose was stained with ethidium bromide (Biotech, Canada), and electrophoresis was done at $100 \mathrm{~V}, 80 \mathrm{~mA}$ for one h. The DNA bands were visualized by a UV trans illuminator (Clinx Science, China).

\section{Phylogenetic analysis}

The amplified 16S rRNA gene of three positive samples by the conventional PCR assay was sent for sequencing (Macrogen, Korea) and analyzed using the MEGA-X program (14) Based on the NCBI-BLAST data, Multiple Sequence Alignment Analysis of 16S rRNA gene, phylogenetic tree, and homology sequence identity were made with the Genbank-NCBI strain/isolate.

\section{Statistical analysis}

All data were documented and analyzed using Microsoft Office Excel and SPSS. Chi-square and t-test were applied to detect significant differences in clinical, serological, and molecular results at $\mathrm{P}<0.05$ (15).

\section{Results}

The serological analysis showed that out of 91 serum samples tested by ELISA, 18 (19.8\%) (95\% Confidence limits 11.6-28.0\%) were positive for $C$. burnetii. In addition, OD values of seropositive camels were ranged 0.481-1.174 and having $0.782 \pm 0.042$.

The molecular assay of whole blood samples showed that $4.4 \%$ (95.6\% Confidence limits $0.08-10.2 \%$ ) of 91 samples were positive for the 16S rRNA gene of $C$. burnetii at $425 \mathrm{bp}$ (Table 1, Figure 1).

The phylogenic analysis of the three positive samples is based on the $16 \mathrm{~S}$ rRNA gene. It showed that the local $C$. burnetii IRAQ/Camel No.1 reported a close relationship to NCBI-BLAST $C$. burnetii ATCC: VR-615 strain-16s ribosomal RNA gene (NR_104916.1) of USA strains. On the 
other hand, the local $C$. burnetii IRAQ/Camel No.2 and IRAQ/Camel No.3 were showed a close relationship to NCBI- BLAST CoxiellaburnetiiCB-30 strains (LC464975.1) of Indonesia strains, at total genetic changes $(0.005 \%)$, the sequences findings were recorded in NCBI under the accession numbers of MN900579.1, MN900580.1, and MN900581.1, respectively (Table 2). Based on the phylogenetic tree, the local $C$. Brunetti strains (IRAQ/Camel-No.1, 2, and 3) showed a significant genetic association to NCBI-BLAST strains of $C$. Brunetti strains at total genetic changes of $0.005 \%$ (Figure 2).

Table 1: Prevalence of $C$. burnetii in female camels by ELISA and PCR

\begin{tabular}{lcccc}
\hline Total No. & Test & Positives & Negatives & Confidence level \\
\hline \multirow{2}{*}{91} & ELISA & $18(19.8 \%)$ & $73(80.2 \%)$ & $11.6-28 \%$ \\
& PCR & $4(4.4 \%)$ & $87(95.6 \%)$ & $0.08-10.2 \%$ \\
\hline
\end{tabular}

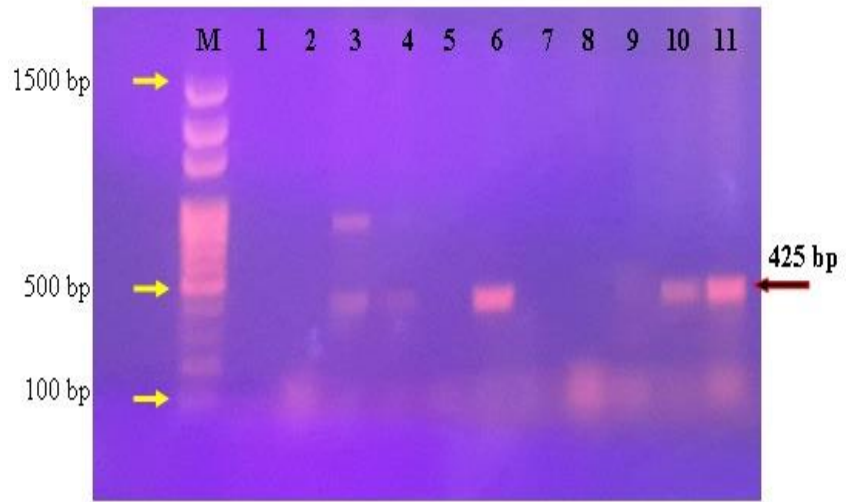

Figure 1: PCR product analysis of $16 \mathrm{~S}$ rRNA gene (425bp) of $C$. burnetii on agarose-gel electrophoresis. M: Ladder marker (100bp); Lane 1 represents negative control; Lanes 2, 5, 7, 8, and 9 represent negative samples; Lanes 3, 4, 6, and 10; Lane 11 represents positive control.

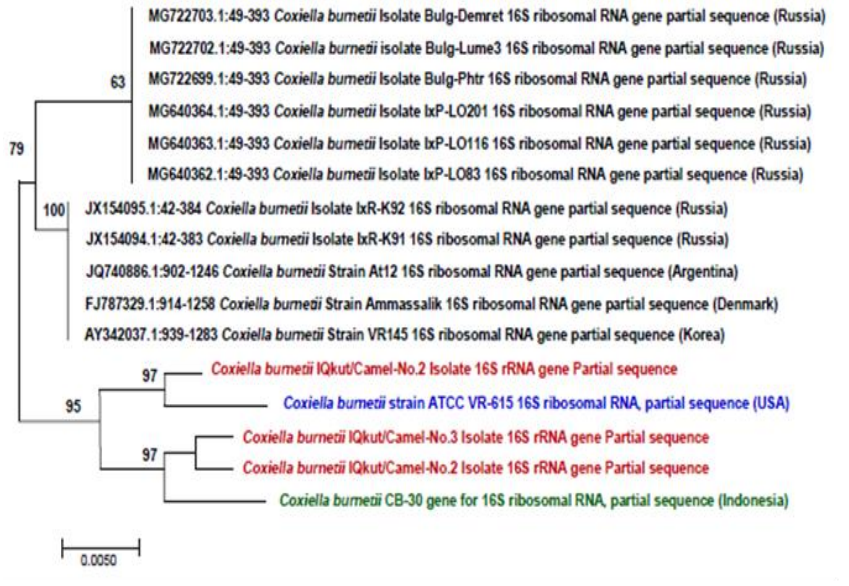

Figure 2: Phylogenetic tree (UPGMA tree) of local isolates and their association with some Genbank-NCBI isolates.

Table 2: Homology Sequence identity between local and NCBI-BLAST C. burnetii strains

\begin{tabular}{cccccc}
\hline \multicolumn{2}{c}{ Local C. burnetii isolate } & \multicolumn{3}{c}{ NCBI-BLAST Homology Sequence identity (\%) } \\
\hline Isolate & Accession No. & Isolate & Accession No. & Country & Identity (\%) \\
\hline IRAQ/Camel-No.1 & MN900579.1 & ATCC: $V R-615$ & NR_104916.1 & USA & $96.52 \%$ \\
IRAQ/Camel-No.2 & MN900580.1 & CB-30 & LC464975.1 & Indonesia & $96.93 \%$ \\
IRAQ/Camel-No.3 & MN900581.1 & CB-30 & LC464975.1 & Indonesia & $96.94 \%$ \\
\hline
\end{tabular}

The clinical examination of camels showed no significant differences in positive camels' temperature, pulse, and respiratory rates using the ELISA and PCR methods compared to negatives (Table 3 ).

Pre-scapular and supra-mammary lymph nodes of all camels were clinically normal at the time of sampling, and no ticks were found in the study. According to the region of the study's camels, significant increases in positive results were reported in areas of Badra by ELISA $42.9 \%$ and PCR $10.71 \%$ (Table 4).

An association of positive findings to the period factor showed significant increases in the positive results by ELISA and PCR methods respectively in April 23.3and 6.7\% and March 20.9 and 4.7\% (Table 5).

Table 3: Results of vital signs of study camels

\begin{tabular}{lcccc}
\hline \multirow{2}{*}{ Factor } & \multicolumn{2}{c}{ ELISA } & \multicolumn{2}{c}{ PCR } \\
\cline { 2 - 5 } & Positive & Negative & Positive & Negative \\
\hline Temperature & $37.54 \pm 1.02$ & $37.18 \pm 0.69$ & $37.91 \pm 0.83$ & $37.33 \pm 0.45$ \\
Pulse rate & $46.21 \pm 2.05$ & $45.82 \pm 1.56$ & $45.93 \pm 1.22$ & $45.61 \pm 1.04$ \\
Respiratory & $9.25 \pm 0.88$ & $9.64 \pm 0.26$ & $9.37 \pm 0.51$ & $9.79 \pm 0.34$ \\
\hline
\end{tabular}


Iraqi Journal of Veterinary Sciences, Vol. 35, Supplement III, 2021 (47-52)

Proceedings of the 13th (2nd International) Scientific Conference, College of Veterinary Medicine, University of Baghdad

Table 4: Total positive results according to the region of study's animals

\begin{tabular}{cccccc}
\hline \multirow{2}{*}{ Region } & \multirow{2}{*}{ No. } & \multicolumn{2}{c}{ ELISA } & \multicolumn{2}{c}{ PCR } \\
\cline { 3 - 6 } & 63 & Positive & Negative & Positive & Negative \\
\hline Al-Numaniyah & $6.52 \%)$ & $57(90.48 \%)$ & $1(1.59 \%)$ & $62(98.41 \%)$ \\
Badra & 28 & $12(42.86 \%) *$ & $16(57.14 \%)$ & $3(10.71 \%) *$ & $25(89.29 \%)$ \\
\hline
\end{tabular}

* Significance at $\mathrm{P}<0.05$.

Table 5: Total positive results according to the period of samples collection

\begin{tabular}{cccccc}
\hline \multirow{2}{*}{ Period } & \multirow{2}{*}{ No. } & \multicolumn{2}{c}{ ELISA } & \multicolumn{2}{c}{ PCR } \\
\cline { 3 - 6 } & & Positive & Negative & Positive & Negative \\
\hline February & 18 & $2(11.1 \%)$ & $16(88.9 \%)$ & $0(0.0 \%)$ & $18(100 \%)$ \\
March & 43 & $9(20.9 \%)^{*}$ & $34(79.1 \%)$ & $2(4.7 \%)$ & $41(95.4 \%)$ \\
April & 30 & $7(23.3 \%) *$ & $23(76.8 \%)$ & $2(6.7 \%)$ & $28(93 . \%)$ \\
\hline
\end{tabular}

* Significance at $\mathrm{P}<0.05$.

\section{Discussion}

Camels are considered multi-purpose animals of high economic importance due to their milk, meat, leather, and soft wool, especially in dry and hot areas (13). Formerly, it was assumed that camels are resistant to many pathogens, usually affecting other animals. However, numerous studies reported that they are susceptible to other livestock populations and act as reservoirs or carriers for several pathogens (11).

In the present study, the anti-C. burnetii antibodies were detected by ELISA in $19.8 \%$ of camels. The seroprevalence of anti- $C$. burnetii in humans and many different animals have been detected in Iraq's neighboring countries such as Saudi Arabia (10), Iran (11), Turkey (16), and Kuwait (17). Our findings are primarily in line with many studies reported in other countries such as Selimand Ali (8), who detected that the seroprevalence rate was $22 \%$ in camel in Egypt; however, our results were lower than detected $71.2 \%$ in Algeria (18), 44\% in Tunisia (19) and 40.7\% in Egypt (20).

The molecular assay showed that the 16S rRNA gene of C. burnetii was detected in whole blood samples of 4 female camels with $4.4 \%$. These results were lower than the molecular detection in the camels recorded $15.9 \%$ in Saudi Arabia (10) and (17.5\%) in Egypt (21). The results of the serological and molecular tests confirmed wide variations in the prevalence of $C$. burnetii among the camel population worldwide. The quarantine measures could influence these variations, type, and sensitivity of diagnostic methods, type of studied sample, age and sex of animals, poor hygienic and sanitary conditions. The current study reveals significant variations between the seropositive rate $19.8 \%$ of ELISA and PCR $4.4 \%$, this shows that only a fraction of exposed animal carries the pathogen at a given time might be due to continuous immunological responses of the infected host, which leads to decrease and/or interrupted shedding of this pathogen (5).
The sequencing of the 16S rRNA gene of our isolates revealed a significant genetic association to NCBI-BLAST strains of $C$. burnetii strains at total genetic changes of $0.005 \%$. Whereas the local C. burnetii IRAQ/Camel No.1 showed a close relationship to the USA (NR_104916.1) strain, the local $C$. burnetii IRAQ/Camel No.2 and IRAQ/Camel No.3 were showed a close relationship to Indonesia (LC464975.1) strains. The 16S rRNA gene sequencing analysis can be used to identify and differentiate phenotypically aberrant, uncultivable, or poorly described microorganisms such as $C$. burnetii (22-24).

In the clinical examination of the study's camels, there are no statistical differences in values of vital signs (temperature, pulse, and respiratory rates) and enlargement in superficial lymph nodes of positive and negative camels. This may be since the infected animals with $C$. burnetii neither revealed the visible clinical signs nor apparent pathological alterations in the tissues, milk, and meat. Consequently, it is unlikely to diagnose this pathogen according to the clinical or postmortem examination (25). Consequently, definitive diagnosis of this disease is based on a significant rise in antibody and molecular detection (2527). The decrease in pregnancy and/or milk production might be attributed to the high susceptibility of $C$ burnetii to the placenta, amniotic fluids, and udder $(8,18)$.

The season and geographical location are the main factors that participated in a high prevalence of $C$. burnetii infection. The significant increases in $C$. burnetii positive camels at Badra compared to the Al-Numaniyah region may be partly correlated with the local ecological factors, such as type of management and practice, flock size, and droughtrelated to low rainfall. Concurrently, this area has been suffering from the dust arising from the regional countries, which is named Middle Eastern Dust. The dust can be carried and transport various pathogens for long distances (28). The windy and dry environments play an essential role in the transport of $C$. burnetii in numerous outbreaks. Worthwhile, Badra is a town in Wasitgovernorate, near the Iraqi- 
Iranian border. In Iran, C. burnetii has been detected in camels and other animal species, as mentioned above (11). A comparison with Iranian strains could demonstrate crossborder transmission.

Finally, the apparent high seroprevalence of $C$. burnetii during the April and March months 23.3 and 20.9\%, respectively, might be attributed to the climatic changes and the high wind activity during these months. These winds commonly facilitate the transmission and inhalation of contaminated dust with this pathogen (28). Furthermore, increasing the activity of the ticks and other arthropods may increase, which plays an essential role in transmitting this bacterium during these months (29).

\section{Conclusion}

Our findings indicate that $C$. burnetii is prevalent among female camels in different areas in Badra and Al-Numaniyah districts in Wasit province, Iraq. Additional molecular studies targeting other genes must be performed to improve the control measures of this highly contagious zoonotic pathogen.

\section{Acknowledgment}

The authors are thankful to the College of Veterinary Medicine (University of Baghdad) and to the College of Veterinary Medicine (Wasit University) for providing the necessary facilities and requirements of the present study. The authors did not receive any funds for the current study.

\section{Conflict of interest}

The authors declare that the current study was carried out without conflict of interest.

\section{References}

1. Markey BK, Leonard FC, Archaicauit M, Cullinane A, Maguire D. Clinical veterinary microbiology. $2^{\text {nd }}$ ed. New York: Mosby Elsevier; 2014. 417.

2. Njeru J, Henning K, Pletz MW, Heller R, Neubauer H. Q fever is an old and neglected zoonotic disease in Kenya: A systematic review. BMC Public Hlth. 2016;5(16):297. DOI: 10.1186/s12889-016-2929-9

3. Devaux CA, Osman IO, Million M, and Raoult D. Coxiella burnetii in dromedary camels (Camelus dromedarius): A possible threat for humans and livestock in north africa and the near and middle east? Front Vet Sci 2020;7:558481. DOI: 10.3389/fvets.2020.558481

4. Gharban HAJ, Yousif AA. First isolation and molecular phylogenetic analysis of Coxiella burnetii in lactating cows, Iraq. Bulgarian J Vet Med. 2020;24. DOI: 10.15547/bjvm.2322

5. Gharban HAJ, Yousif AA. Serological and molecular phylogenetic detection of Coxiella burnetii in lactating cows, Iraq. Iraqi J Vet Med. 2020;44:1-5. DOI: 10.30539/ijvm.v44i(E0). 1020

6. Hussein MF, Alshaikh MA, Al-Jumaah RS, GarelNabi A, Al-Khalifa I, and Mohammed OB. The arabian camel (Camelus dromedarius) is a major reservoir of Q fever in Saudi Arabia. Comp Clin Pathol. 2015;24 (4):887-892. DOI: $10.1007 / \mathrm{s} 00580-014-2002-\mathrm{y}$
7. Afzal M, Sakkir M. Survey of antibodies against various infectious disease agents in racing camels in Abu Dhabi, United Arab Emirates. Rev Sci Tech OIE. 1994;13:787-92. DOI: 10.20506/rst.13.3.794

8. Selim A and Ali A. Seroprevalence and risk factors for $C$. burentii infection in camels in Egypt. Comp Immunol Microbiol Infect Dis. 2020;68:101402. DOI: 10.1016/j.cimid.2019.101402

9. Bellabidi M, Benaissa MH, Bissati-Bouafia S, Harrat Z, Brahmi K, Kernif T. Coxiella burnetii in camels (Camelus dromedarius) from Algeria: Seroprevalence, molecular characterization, and ticks (Acari: Ixodidae) vectors. Acta Trop. 2020;206:105443. DOI: 10.1016/j.actatropica.2020.105443

10. Mohammed OB, Jarelnabi AA, Aljumaah R, Alshaikh MA, Bakhiet AO, Omer SA and Hussein MF. Coxiella burnetii, the causative agent of Q fever in Saudi Arabia: molecular detection from camel and other domestic livestock. Asian Pac J Trop Med. 2014;7(9):715-719. DOI: 10.1016/S1995-7645(14)60122-X

11. Pirouz HJ, Mohammadi G, Mehrzad J, Azizzadeh M, Hossein M and Shirazi N. Seroepidemiology of $\mathrm{Q}$ fever in one-humped camel population in northeast Iran. Trop Anim Hlth Prod. 2015;47(7):1293-8. DOI: $10.1007 / \mathrm{s} 11250-015-0862-\mathrm{Z}$

12. Gharban HAJ, Yousif AA. Serological, clinical, and hematological prevalence of Coxiella burnetii in adult cows, Iraq. Biochem Cell Arch. 2020;20(1):67-74 DOI: $10.35124 /$ bca.2020.20.1.67

13. Kadim IT, Mahgoub O, Purchas RW. A review of the growth and of the carcass and meat quality characteristics of the one-humped camel (Camelus dromedaries). Meat Sci. 2008;80(3):555-69. DOI: 10.1016/j.meatsci.2008.02.010

14. Newman L, Duffus ALJ, Lee C. Using the free program MEGA to build phylogenetic trees from molecular data. Am Biol Teach. 2016;78(7):608-612. DOI: 10.1525/abt.2016.78.7.608

15. Neyeloff JL, Fuchs SC, Moreira LB. Meta-analyses and Forest plots using a microsoft excel spreadsheet: step-by-step guide focusing on descriptive data analysis. BMC Res Notes. 2012;5:52. DOI: 10.1186/1756-0500-5-52

16. Zhu S, Zimmerman D, Deem SLA. Review of zoonotic pathogens of dromedary Camels. Eco Hlth. 2019;16:356-77. DOI: 10.1007/s10393019-01413-7

17. Leski TA, Malanoski AP, Gregory MJ Lin B, Stenger DA. Application of a Broad-range resequencing array for detection of pathogens in desert dust samples from Kuwait and Iraq. Appl Environ Microbiol. 2011;77(13):4285-92. DOI: 10.1128/AEM.0002111

18. Benaissa MH, Ansel S, Mohamed-Cherif A, Benfodil K, Khelef D, Youngs CR, Ait-Oudhia K. Seroprevalence and risk factors for Coxiella burnetii, the causative agent of $\mathrm{Q}$ fever in the dromedary camel (Camelusdromedarius) population in Algeria. Onderstepoort $\mathrm{J}$ Vet Res. 2017;31:84(1):e1-e7. DOI: 10.4102/ojvr.v84i1.1461

19. Selmi R, Mamlouk RA, Yahia HB, Abdelaali H, Said MB, Sellami K, Daaloul-Jedidi M, Jemli MH, Message L. Coxiella burnetii in Tunisian dromedary camels (Camelus dromedarius): seroprevalence, associated risk factors, and seasonal dynamics. Acta Trop. 2018;188:234-239. DOI: 10.1016/j.actatropica.2018.09.008

20. KlemmerJ, Njeru J, Emam A, El-Sayed A, Moawad AA, Henning K, and El-Diasty MM. Q fever in Egypt: Epidemiological survey of Coxiella burnetii specific antibodies in cattle, buffaloes, sheep, goats, and camels. PLoS One. 2018:13(2):e0192188. DOI: 10.1371/journal.pone.0192188

21. Ali SF, Ibrahim EM, and El Jake J. Molecular and serological studies on Coxiella burnetii in camels at Marsa Matrouh governorate in Egypt. J Am Sci. 2016;12(1):77-82. DOI: 10.7537/marsjas12011610

22. Clarridge J. Impact of $16 \mathrm{~S}$ rRNA gene sequence analysis for identification of bacteria on clinical microbiology and infectious diseases. Clin Microbiol Rev. 2004;17(4):840-62. DOI: 10.1128/CMR.17.4.840-862.2004

23. Petti CA, Polage CR, Schreckenberger P. The role of $16 \mathrm{~S}$ rRNA gene sequencing in identification of microorganisms misidentified by conventional methods. J Clin Microbiol. 2005;43(12):6123-5. DOI: 10.1128/JCM.43.12.6123-6125.2005

24. McLaughlin HP, Cherney B, Hakovirta JR, Priestley RA, Conley A, Carter A, Sue D. Phylogenetic inference of Coxiella burnetii by $16 \mathrm{~S}$ 
rRNA 18-gene sequencing. PLoS One. 2017;12(12):e0189910. DOI: 10.1371/journal.pone.0189910

25. Angelakis E, Raoult D. Q fever. Vet Microbiol. 2010;27;140(3-4):297309. DOI: 10.1016/j.vetmic.2009.07.016

26. Alfatlawy HH, Alfatlawi MA. Morphological and molecular identification of Parabronema skrjabini of camels (Camelus dromedary) in Najaf province. Iraqi J Vet Sci. 2021;35(3):507-512. DOI: $10.33899 /$ ijvs.2020.127101.1459

27. Saeed ZK, Abbas BA, Othman RM. Molecular identification and phylogenetic analysis of lactic acid bacteria isolated from goat raw milk. Iraqi J Vet Sci. 2020;34(2):259-263. DOI: 10.33899/ijvs.2020.126914.1415

28. Tissot-Dupont H, Amadei MA, Nezri M, Raoult D. Wind in November, Q fever in December. Emerg Infect Dis. 2004;10(7):1264-9. DOI: 10.3201/eid1007.030724

29. Kaaboub EA, Ouchene N, Ouchene-Khelifi NA, Dahmani A, Ouchetati I, Haif, Khelef D. Investigation of the principal vectors of abortive diseases in one-humped camels (Camelus dromedarius). Iraqi J Vet Sci. 2021;35(3):411-415. DOI: 10.33899/ijvs.2020.126914.1415
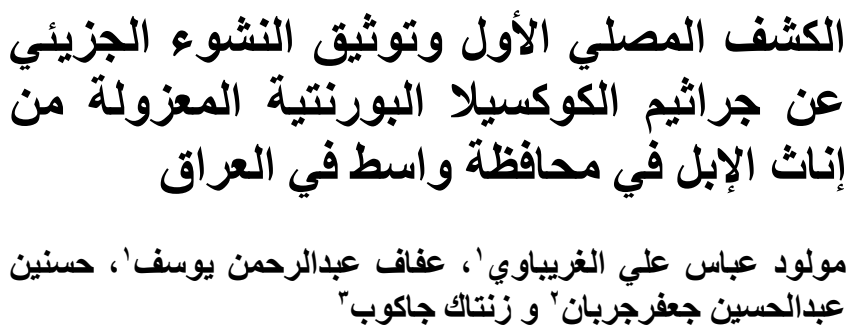

'فرع الطب الباطني و الوقائي، كلية الطب البيطري، جامعة بغداد، بغداد،

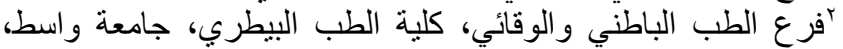

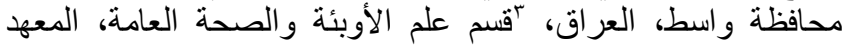

السويسري للصحة الاستو ائية و العامة، جامعة بازية الأل، بازل، سويسرا

الخلاصة

إن هذه الدر اسة تهدف الكثفف عن جراثيم الكوكسيلا البورنتية في

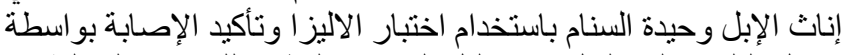

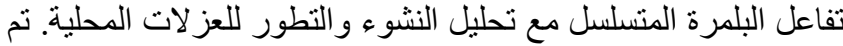

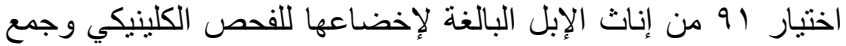

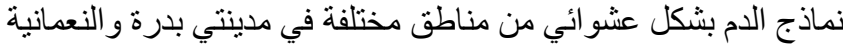

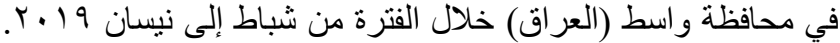

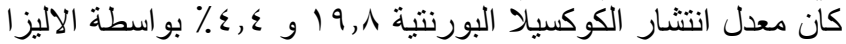

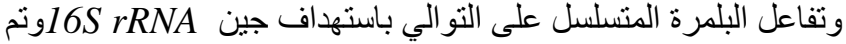
توثيق الحمض النووي الجيني لثناث عينات إيجابية في -Genbank تحت أرقام الانضمام MNCBI

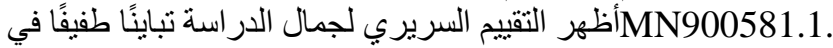
قيم درجة الحرارة والنبض ومعدلات التنفس وتضخم العقدة الليمفاوية

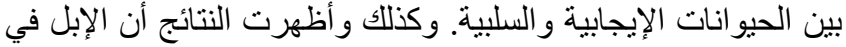
منطقة بدرة كانت إيجابية بشكل معنوي للكوكسيلا البورنتية مقارنة

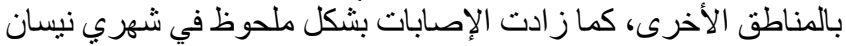
و أيار، أكدت النتائج التي توصلنا إليها انتشار جر اثيم الكوكسيلا البورنتية الإنية

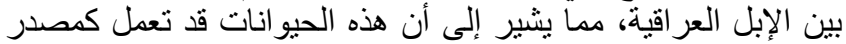

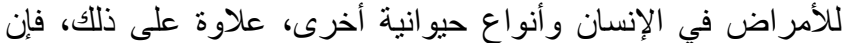
الدر اسات ضرورية لتوفير بيانات أكثر تفصيلاً حول انتشار التشار الكوكسيلا البورنتية لتحسين خطط السيطرة. 